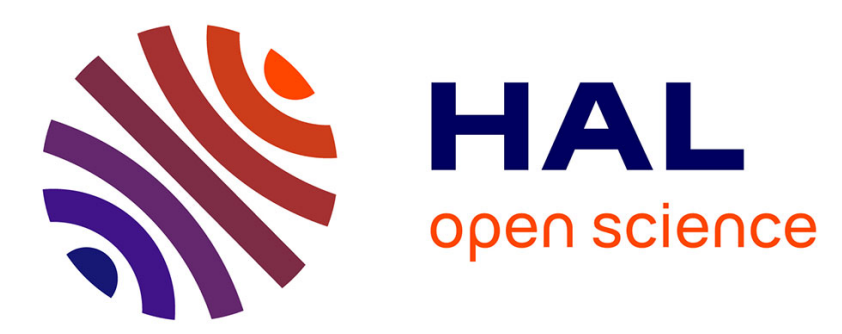

\title{
A scientific note on the lack of effect of mandible ablation on the synthesis of royal scent by honeybee queens
}

Huo-Qing Zheng, Vincent Dietemann, Fu-Liang Hu, Robin Crewe, Christian Pirk

\section{To cite this version:}

Huo-Qing Zheng, Vincent Dietemann, Fu-Liang Hu, Robin Crewe, Christian Pirk. A scientific note on the lack of effect of mandible ablation on the synthesis of royal scent by honeybee queens. Apidologie, 2012, 43 (4), pp.471-473. 10.1007/s13592-011-0114-9 . hal-01003538

\section{HAL Id: hal-01003538 \\ https://hal.science/hal-01003538}

Submitted on 1 Jan 2012

HAL is a multi-disciplinary open access archive for the deposit and dissemination of scientific research documents, whether they are published or not. The documents may come from teaching and research institutions in France or abroad, or from public or private research centers.
L'archive ouverte pluridisciplinaire HAL, est destinée au dépôt et à la diffusion de documents scientifiques de niveau recherche, publiés ou non, émanant des établissements d'enseignement et de recherche français ou étrangers, des laboratoires publics ou privés. 


\title{
A scientific note on the lack of effect of mandible ablation on the synthesis of royal scent by honeybee queens
}

\author{
Huo-Qing Zheng ${ }^{1}$, Vincent Dietemann ${ }^{2,3}$, Fu-Liang Hu${ }^{1}$, Robin M. Crewe $^{3}$, Christian W. W. Pirk ${ }^{3}$ \\ ${ }^{1}$ College of Animal Sciences, Zhejiang University, Hangzhou 310058, China \\ ${ }^{2}$ Swiss Bee Research Centre, Agroscope Liebefeld-Posieux Research Station ALP, CH-3003 Bern, Switzerland \\ ${ }^{3}$ Social Insect Research Group, Department of Zoology \& Entomology, University of Pretoria, Pretoria 0002, Republic of \\ South Africa
}

Received 2 August 2011 - Revised 2 November 2011 - Accepted 2 December 2011

mandible ablation / queen pheromone / mandibular gland / honeybee queen / multiple queen colony

Recently, honeybee colonies in which several mated, egg-laying honeybee queens coexist under freely moving conditions were experimentally obtained mainly by ablating a third to a half of both mandibles of queens to avoid inter-queen rivalry (Zheng et al. 2009a). These colonies functioned normally and were used as supporting units for the faster build-up of productive colonies and for production of royal jelly in China (Zheng et al. 2009b). Observations also revealed that queens with a third to a half of one mandible ablated had normal levels of activity compared to intact queens, but they refrained from engaging in lethal contests (Dietemann et al. 2008). Mandibles are the release site of the mandibular glands pheromone. This pheromone possesses many functions (reviewed in Le Conte and Hefetz 2008), among which is the regulation of reproduction of workers. Since the secretory openings of mandibular glands are located at the inner margin of each mandible between the anterior articulation and the base of the apodeme of the flexor muscle (Snodgrass 1956; Figure 1), the gland's secretions might be affected by partial mandible ablation. Ablation could block or facilitate the release of the pheromone via feedback mechanisms and could thus influence the synthesis rate of the gland or the proportion of its components. We therefore evaluated the effect of this surgical treatment on the composition of the queen mandibular gland pheromone to determine whether

Corresponding author: F. Hu,

flhu@zju.edu.cn

Manuscript editor: David Tarpy changes in its synthesis could play a role in the experimental establishment of polygyny.

The honeybee colonies used were Apis mellifera ligustica. Queens were freely mated 1-year-old sisters reared as those used to create multiple-queen colonies (Zheng et al. 2009a). Seventeen queens were collected and a third to a half of one of their mandibles (left side for eight and right side for nine queens) was excised with micro-scissors (Zheng et al. 2009a). In order to investigate the effect of removing a part of the mandible on queen pheromone synthesis, eight of these queens (four of which the left mandible was manipulated and four with the right) were each introduced into a queenless colony with four frames of bees to form single-queen colonies.

To evaluate the potential changes in pheromone synthesis in ablated queens in the context of a multiplequeen colony, the other nine ablated queens were introduced into three queenless colonies with four frames of young bees to form three-queen colonies (Zheng et al. 2009a). One queen in each of two colonies failed to be accepted. One three-queen and two two-queen colonies were thus used.

The 11 colonies were kept for 10 days when at least one comb in each colony was filled with eggs and young larvae. Queens were then taken out of their hosting colonies, frozen, and decapitated.

The heads were split into two parts by vertically cutting between the mandibles and the bases of the antennae (Figure 1). Half heads were placed in $200 \mu \mathrm{L}$ dichloromethane for at least $24 \mathrm{~h}$ to allow maximal extraction of gland content. This method does not allow the distinction between gland content 


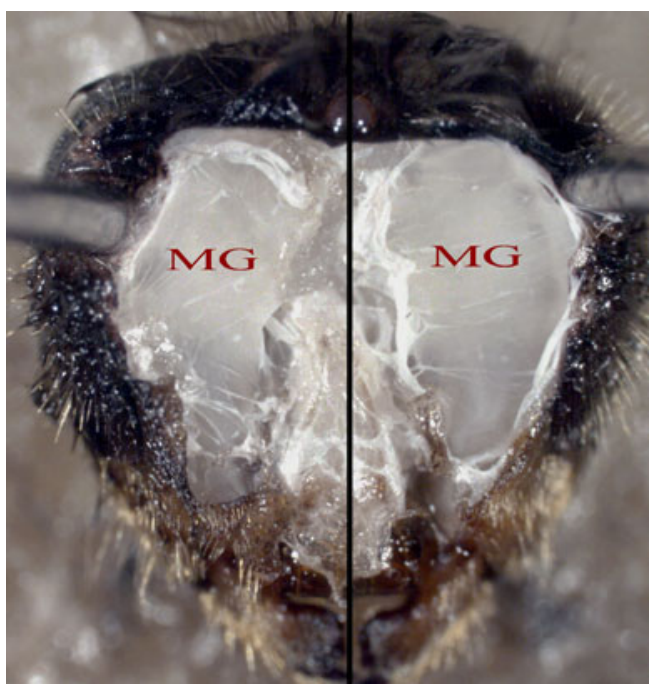

Figure 1. Anterior view of head of queen. $M G$ indicates mandibular gland. The heads were split into two parts following the vertical black line to obtain two halves carrying either the partially ablated mandible or the intact mandible.

and secreted blend. Since the quantity of pheromone stored in a gland is two to three orders of magnitude higher than that found on the cuticle (Naumann et al. 1991), our extracts reflect the amount of pheromone synthesized by the gland. Half of the extract was evaporated under a stream of nitrogen and analyzed by gas chromatography (see Zheng et al. 2010). The following six mandibular gland components were identified based on the retention times of synthetic compounds and quantified using peak areas: 9-keto(E)-2 decenoic acid (9ODA), 9-hydroxy-2(E)-dece- noic acid (9HDA), the two aromatic compounds methyl p-hydroxybenzoate (HOB) and 4-hydroxy-3methoxyphenylethanol (HVA), and two major worker mandibular gland components 10-hydroxy-2(E)decenoic acid (10HDA) and 10-hydroxydecanoic acid (10HDAA). Their relative mass ratios were calculated relative to tetradecane.

Since the absolute amount and relative proportions (data arcsine transformed) of the six compounds did not vary significantly between left and right half heads either with ablated or intact mandibles in either monogynous queens or polygynous queens, data from left half heads and right half heads were pooled (Mann-Whitney $U$ test, $0 \leq$ $U_{(3 \sim 4)} \leq 8$, lowest $P$ value $\left.=0.057\right)$.

Both the absolute amounts and relative proportions (data arcsine transformed) of the six individual compounds and their total quantity showed no significant differences between the ablated and intact half heads of both monogynous and polygynous queens (Figure 2, Wilcoxon signed ranks test, $-2<\mathrm{Z}_{(7 \sim 8)}<0$, lowest $P$ value $=$ 0.176 ). We therefore pooled the data for monogynous and polygynous queens. Again, no significant difference was found between ablated and intact groups (Wilcoxon signed ranks test, $-2<\mathrm{Z}_{15}<0$, lowest $P$ value $=0.281$ ).

No significant difference between intact and ablated half heads was found in the ratio of 10HDAA/9HDA that is used to differentiate between worker $(>1.0)$ and queen-specific signals $(\leq 1.0)$ (Plettner et al. 1993) (Wilcoxon signed ranks test, $Z_{15}=-1.420, P=0.156$ ) or in the ratio of 9ODA/ (9ODA+10HDAA+10HDA) commonly used as a measure of reproductive dominance (Moritz et al. 2004) (Wilcoxon signed ranks test, $Z_{15}=-0.227, P=$

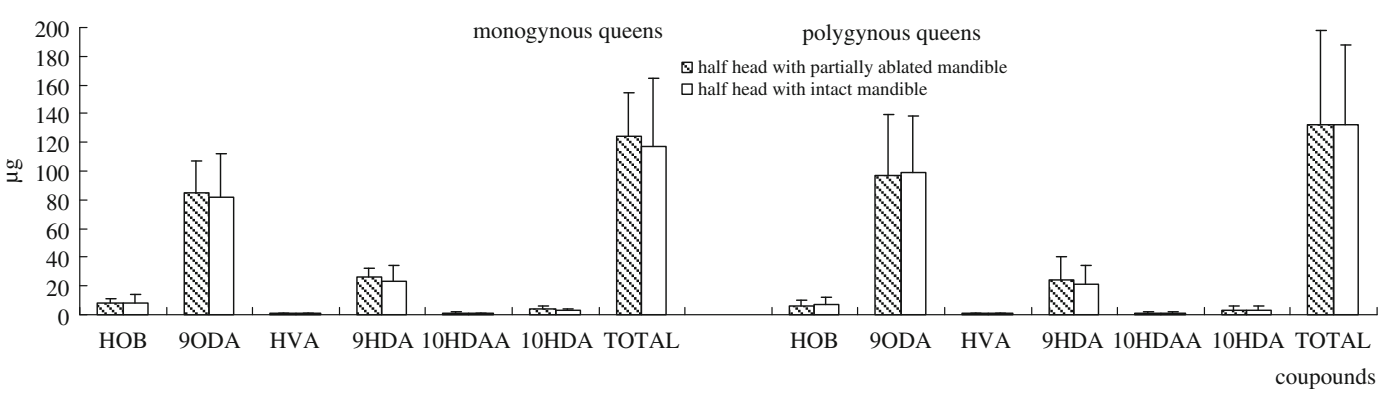

Figure 2. Absolute amounts (average $\pm \mathrm{SD}$ ) of the six compounds of the honeybee queen mandibular blend. Neither absolute nor total amount of the compounds showed statistical differences between half heads with partially ablated or intact mandibles (Wilcoxon signed rank test). 
0.820 ). The power values of our tests (MannWhitney $U$ and Wilcoxon signed rank tests) were between 0.05 for 9ODA and 0.109 for 9HDA ( $g$ *Power 3.1 for MAC).

No significant difference could be found in pheromonal synthesis by glands connected to an ablated or intact mandible. Given the power of our tests, we can state that pheromone synthesis in glands from ablated and non-ablated half heads are not statistically different. The ablation of a third to half of a mandible therefore does not seem to significantly affect the synthesis of mandibular pheromone by the corresponding gland. We have thus found no evidence for a feedback mechanism that affects the synthesis of pheromone when the release site has been manipulated. Our results support the idea that experimentally established polygyny by mandible ablation (Dietemann et al. 2008) is not due to changes in mandibular pheromones.

The amounts of compounds extracted from ablated individuals are comparable to non-ablated controls and to values measured in other studies [for example, $179.5 \pm 65 \mu \mathrm{g}$ for 9-ODA in our study compared to $231 \pm 17 \mu \mathrm{g}$ by Plettner et al. (1997)]. This indicates that ablated queens do not have a reduced ability to synthesize mandibular pheromone compared to unmanipulated queens.

In our study, we only measured the composition of the mandibular gland products that was synthesized and not the pheromone available to detection by the workers on the surface of the queen's cuticle. A finer resolution of the effect of ablation on chemical communication could therefore be obtained if the pheromone extracted from queen cuticle and not from their glands was investigated.

Not only mandibular pheromones are changing with the reproductive status of honeybees, Dufour gland secretions are also described as a fertility signal in workers (Malka et al. 2007). It is unlikely that manipulation of the mandible affects this gland's secretion, but whether they are involved in the establishment of polygynous honeybee colonies should be investigated. Excluding changes in pheromonal secretion following ablation supports the hypothesis that experimental polygyny in honeybees is a result of self-assessment of the fighting ability of queens (Dietemann et al. 2008).

\section{ACKNOWLEDGMENTS}

This work was funded by China Postdoctoral Science Foundation (20100481435 and 201104739) and RMC and CWWP were funded by National Research Foundation and University of Pretoria.

\section{Note scientifique sur l'absence d'effet de l'ablation de la mandibule sur la synthèse de la phéromone royale par les reines d'abeilles.}

Eine wissenschaftliche Notiz darüber, dass die Ablation der Mandibeln keinen Effekt auf die Synthese der Königinnenduftstoffe bei Honigbienen hat.

\section{REFERENCES}

Dietemann, V., Zheng, H.Q., Hepburn, C., Hepburn, H.R., Jin, S.H., Crewe, R.M., Radloff, S.E., Hu, F.L., Pirk, C.W.W. (2008) Self assessment in insects: honeybee queens know their own strength. PLoS One 3, e1412

Le Conte, Y., Hefetz, A. (2008) Primer pheromones in social Hymenoptera. Annu. Rev. Entomol. 53, 523-542

Malka, O., Shnieor, S., Hefetz, A., Katzav-Gozansky, T. (2007) Reversible royalty in worker honeybees (Apis mellifera) under the queen influence. Behav. Ecol. Sociobiol. 61, 465-473

Moritz, R.F.A., Lattorff, H.M.G., Crewe, R.M. (2004) Honeybee workers (Apis mellifera capensis) compete for producing queen-like pheromone signals. P. Roy. Soc. B-Biol. Sci. 271, S98-S100

Naumann, K., Winston, M.L., Slessor, K., Prestwich, G.D., Webster, F.X. (1991) Production and transmission of honey bee queen (Apis mellifera L.) mandibular gland pheromone. Behav. Ecol. Sociobiol. 29, 321-332

Plettner, E., Otis, G.W., Winmalaratne, P.D.C., Winston, M.L., Slessor, K.N., Pankiw, T., Punchihewa, P.W.K. (1997) Species- and caste-determined mandibular gland signals in honeybees (Apis). J. Chem. Ecol. 23, 363-377

Plettner, E., Slessor, K.N., Winston, M.L., Robinson, G.E., Page, R.E. (1993) Mandibular gland components and ovarian development as measures of caste differentiation in the honey bee (Apis mellifera L.). J. Insect Physiol. 39, 235-240

Snodgrass, R.E. (1956) Anatomy of the honey bee, pp. 39-42. Cornell University Press, Ithaca

Zheng, H.Q., Dietemann, V., Crewe, R.M., Hepburn, H.R., Hu, F.L., Yang, M.X., Pirk, C.W.W. (2010) Pheromonal predisposition to social parasitism in the honeybee Apis mellifera capensis. Behav. Ecol. Sociobiol. 21, 1221-1226

Zheng, H.Q., Jin, S.H., Hu, F.L., Pirk, C.W.W. (2009a) Sustainable multiple queen colonies of honeybees, Apis mellifera ligustica. J. Apic. Res. 48, 284-289

Zheng, H.Q., Jin, S.H., Hu, F.L., Pirk, C.W.W., Dietemann, V. (2009b) Maintenance and application of multiple queen colonies in commercial beekeeping. J. Apic. Res. 48, 290295 